\title{
AIDS-RELATED PROGRESSIVE MULTIFOCAL LEUKOENCEPHALOPATHY: A RETROSPECTIVE STUDY IN A REFERRAL CENTER IN SÃO PAULO, BRAZIL
}

\author{
José E. VIDAL(1,2), Augusto C. PENALVA DE OLIVEIRA(1,3), Maria Cristina D.S. FINK(4), Cláudio S. PANNUTI(4) \& J. Roberto TRUJILLO(5)
}

\begin{abstract}
SUMMARY
Few data are available about progressive multifocal leukoencephalopathy (PML) in patients with acquired immunodeficiency syndrome (AIDS) from Brazil. The objectives of this study were to describe the main features of patients with PML and estimate its frequency among AIDS patients with central nervous system (CNS) opportunistic diseases admitted to the Instituto de Infectologia Emílio Ribas, São Paulo, Brazil, from April 2003 to April 2004. A retrospective and descriptive study was performed. Twelve (6\%) cases of PML were identified among 219 patients with neurological diseases. The median age of patients with PML was 36 years and nine $(75 \%)$ were men. Nine $(75 \%)$ patients were not on antiretroviral therapy at admission. The most common clinical manifestations were: focal weakness (75\%), speech disturbances (58\%), visual disturbances (42\%), cognitive dysfunction (42\%), and impaired coordination (42\%). The median CD4+ T-cell count was 45 cells/ $\mu \mathrm{L}$. Eight $(67 \%)$ of 12 patients were laboratoryconfirmed with PML and four (33\%) were possible cases. Eleven $(92 \%)$ presented classic PML and only one case had immune reconstitution inflammatory syndrome (IRIS)-related PML. In four (33\%) patients, PML was the first AIDS-defining illness. During hospitalization, three patients $(25 \%)$ died as a result of nosocomial pneumonia and nine $(75 \%)$ were discharged to home. Cases of PML were only exceeded by cases of cerebral toxoplasmosis, cryptococcal meningoencephalitis, and CNS tuberculosis, the three more frequent neurologic opportunistic infections in Brazil. The results of this study suggest that PML is not an uncommon HIV-related neurologic disorder in a referral center in Brazil.
\end{abstract}

KEYWORDS: Progressive multifocal leukoencephalopathy; Epidemiology; Diagnosis; Acquired immunodeficiency syndrome.

\section{INTRODUCTION}

Progressive multifocal leukoencephalopathy (PML) is a disease of the central nervous system (CNS) caused by the virus JC and characterized by lytic infection of the oligodendrocytes and demyelination ${ }^{10}$, tipically occuring in the context of severe immunodepression. After the advent of the HIV epidemic, acquired immunodeficiency syndrome (AIDS) became the most common predisposing disorder for PML ${ }^{1}$. This disease has been diagnosed in up to $5 \%$ of $\mathrm{HIV}$-infected patients in developed countries in the pre highly active antiretroviral therapy (HAART) era ${ }^{10}$. However, the incidence of PML has decreased less dramatically when compared to other CNS diseases in the HAART era ${ }^{6,21}$. Interestingly, PML has rarely been reported in HIV-infected patients from developing countries ${ }^{8,11,12}$. The objectives of this study were to describe the clinical and radiological features of patients with PML and estimate its frequency among AIDS patients with CNS opportunistic diseases admitted in a referral center in Brazil.

\section{PATIENTS AND METHODS}

We performed a retrospective and descriptive study at the Instituto de Infectologia Emílio Ribas, São Paulo, Brazil, from April 2003 to April 2004. All adult HIV-infected patients admitted with a defined diagnosis of a CNS opportunistic disease were included. For this purpose, the records of the following institutions were revised and selected for patients with PML: 1) Laboratory and Department of Neurology at the Instituto de Infectologia Emílio Ribas, and 2) Laboratory of Virology at the Instituto de Medicina Tropical de São Paulo. This study was approved by the Institutional Review Board of the Instituto de Infectologia Emílio Ribas.

The diagnosis of PML was classified as follows: histologyconfirmed PML (clinical and radiological features consistent with PML associated with histopathological diagnosis); laboratory-confirmed PML (compatible clinical and radiological features associated with the presence of JC virus DNA in cerebrospinal fluid -CSF-); and possible PML (clinical and radiological findings consistent with PML) ${ }^{4}$. In addition, PML was classified by classic (PML in the setting of severe immunodeficiency) and immune reconstitution inflammatory syndrome (IRIS)-related PML ${ }^{10}$. Inflammatory PML occurs in the setting of a recovery of the immune system marked by an increase in CD4+ T cell counts and a decrease in HIV plasma viral load ${ }^{10}$. The criteria for

(1) Departamento de Neurologia, Instituto de Infectologia Emílio Ribas, São Paulo, SP, Brasil.

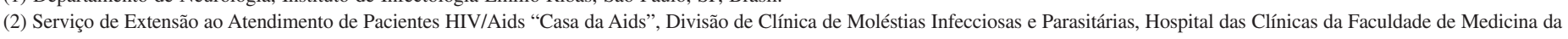
Universidade de São Paulo, São Paulo, SP, Brasil.

(3) Unidade de Pesquisa Clínica em Retroviroses Humanas, Universidade de Campinas, São Paulo, SP, Brasil.

(4) Laboratório de Virologia, Instituto de Medicina Tropical de São Paulo, Universidade de São Paulo, São Paulo, SP, Brasil.

(5) Institute of Human Virology, School of Medicine, University of Maryland, USA.

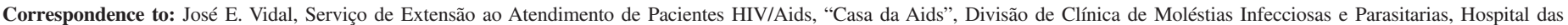

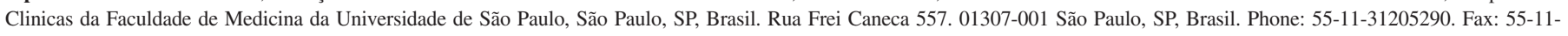




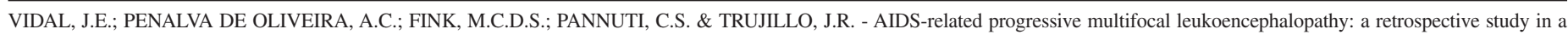
referral center in São Paulo, Brazil. Rev. Inst. Med. trop. S. Paulo, 50(4): 209-212, 2008.

cerebral toxoplasmosis, cryptococcal meningoencephalitis, CNS tuberculosis, CNS cytomegalovirus, and primary CNS lymphoma were defined according to a recent consensus ${ }^{17}$. Neurosyphilis was diagnosed in patients with a reactive Venereal Disease Research Laboratory in CSF. Trypanosoma cruzi meningoencephalitis diagnosis was based on the direct identification of $T$. cruzi in CSF. BK virus meningoencephalitis was based on clinical and radiological features of meningoencephalitis associated with a presence of BK virus DNA in CSF and brain tissue. The polymerase chain reaction (PCR) for JC virus DNA in CSF samples was performed using primers to amplify the T-antigen genes (173 bp) from both BK virus and JC virus. The presence of the JC virus was confirmed by digestion of the PCR product using BamH1, as previously described ${ }^{7}$. HIV infection was documented by HIV-1 antibody enzyme-linked immunosorbent assay and Western blot analysis.

\section{RESULTS}

A total of $219 \mathrm{HIV}$-infected patients with CNS opportunistic diseases were included. Twelve (6\%) patients presented with PML, which was the fourth most frequent opportunistic complication after cerebral toxoplasmosis $(\mathrm{n}=110,50 \%)$, cryptococcal meningoencephalitis $(\mathrm{n}=53,24 \%)$, and CNS tuberculosis $(\mathrm{n}=32$, $15 \%)$. Other diagnoses were neurosyphilis $(\mathrm{n}=4,2 \%)$, primary CNS lymphoma ( $\mathrm{n}=3,1 \%)$, CNS cytomegalovirus $(\mathrm{n}=3,1 \%)$, T. cruzi meningoencephalitis $(\mathrm{n}=1,0.4 \%)$, and $\mathrm{BK}$ virus meningoencephalitis $(\mathrm{n}=1,0.4 \%)$. The last two cases were previously published ${ }^{13,23}$.

Of the 12 patients with PML, eight (67\%) were laboratoryconfirmed and four $(33 \%)$ were possible cases. There were no cases of histology-confirmed PML. Eleven (92\%) patients presented with classic PML and only one case had IRIS-related PML. All patients were aware of their HIV status at admission. In four (33\%) patients, PML was the first AIDS-defining illness. Nine (75\%) patients were not on antiretroviral therapy at admission and were placed on HAART within the first two weeks of diagnosis of PML. The median time of HAART use in the other three patients was two months (range: 1-3 months), and none of them were virologically suppressed at admission (detection limit of HIV-1 viral load $=400$ copies $/ \mathrm{mL}$ ). The median age of patients with PML was 36 years (range: 25-52 years), and nine $(75 \%)$ were men. The most common clinical manifestations were focal weakness (75\%), speech disturbances (58\%), visual disturbances (42\%), cognitive dysfunction (42\%), and impaired coordination $(42 \%)$. Seizures were reported in only one $(8 \%)$ case. The median of CD4+ T-cell count was 45 cells/ $\mu \mathrm{L}$ (range: $3-210$ cells $/ \mu \mathrm{L}$ ). Brain computed tomography (CT) imaging showed multiple hypodense areas in the white matter in nine patients and a single hypodense area in three patients. Magnetic resonance imaging (MRI) was performed in seven patients, and in all cases, multiple hyperintense areas on T2-weighted and fluid attenuated inversion recovery images were observed in the white matter of the cerebral hemispheres. In addition, five $(42 \%)$ of these patients showed lesions in the cerebellum or brain stem. The single patient with IRIS-related PML presented with areas of peripheral enhancement with contrast media associated to discrete mass effect on both CT and MRI. During hospitalization, three patients $(25 \%)$ died as a result of nosocomial pneumonia and nine $(75 \%)$ were discharged to home.

\section{DISCUSSION}

We found that the frequency of PML in this hospital-based study was $6 \%$, similar to that found in developed countries in the pre-HAART era. The results of this study suggest that PML is not an uncommon HIV-related neurological disorder in our setting. Cases of PML were only exceeded by cases of cerebral toxoplasmosis, cryptococcal meningoencephalitis, and CNS tuberculosis, the three more frequent and well described neurological opportunistic infections in most of developing countries, including Brazil.

All PML patients included in this study were aware of their HIV status and presented with low CD4+ T cell counts. We have observed similar profiles in other neurological disorders associated with HIV-1 infection when HAART has not being used ${ }^{24}$.

Clinical, laboratory and radiological presentation of the present series of cases was similar to what has been previously described ${ }^{10,19}$. Although most of the patients presented with classic PML, and only one $(8 \%)$ had IRIS-related PML, a prior study reported this clinical presentation in $19 \%$ of cases ${ }^{3}$.

There are a few reports of PML in Brazil. Five pathological studies which examined a total 519 Brazilian HIV-infected patients, 90\% of whom were observed in the pre-HAART era, showed only two cases of PML $(0.4 \%)^{2,5,14,20,25}$. In a clinical study of 172 patients from the pre-HAART era, only two cases of possible PML were reported $(1 \%)^{18}$. In contrast, a more recent assessment of 194 patients with neurological diseases during the HAART-era showed seven $(4 \%)$ cases of possible $\mathrm{PML}^{15}$. In addition, our group recently reported 27 cases of laboratoryconfirmed PML, and showed that this disease was the most prevalent disorder among 56 HIV-infected patients with focal brain lesions and without mass effect ${ }^{7}$.

The results of the present study suggest that PML might be more frequently diagnosed in developing countries when modern diagnostic procedures can be employed. For example, a recent survey in Uganda found that four $(8 \%)$ of $50 \mathrm{HIV}$-infected patients with neurologic symptoms yielded the presence of JC virus DNA in CSF (C. Pierotti and P. Cinque, personal communication). Several possible reasons may explain the low prevalence reported of PML in developing countries ${ }^{22}$. First, there may be underdiagnosis or underreporting because of difficult access to reference centers with experienced clinicians and adequate diagnostic support, including molecular diagnosis, neuroimaging, neurosurgery, and low necropsy rates. Second, death may be due to other causes, such as opportunistic infections that require less immunosupression than PML and continue to increased morbidity and mortality, such as pneumonia due to Pneumocystis jiroveci and tuberculosis. Furthermore, progressive improvement in medical care and access to health services could explain the prolonged life span in HIVinfected patients, predisposing to the presence of opportunistic diseases that require more immunosuppression, such as PML. Third, there may be possible interactions between JC virus and the different HIV-1 clades. The low prevalence of PML in geographic areas where the HIV-1 subtype $\mathrm{C}$ predominates, including India and Africa, might involve different biological interactions between the two virus. Conversely, in Brazil, similar to United States and Europe, the most prevalent subtype is B, especially in southeastern Brazil, including São Paulo, Rio de Janeiro 


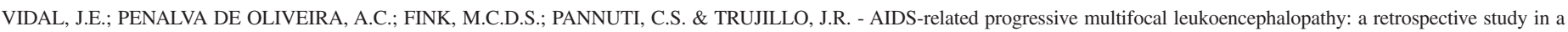
referral center in São Paulo, Brazil. Rev. Inst. Med. trop. S. Paulo, 50(4): 209-212, 2008.

and Minas Gerais States, from where most PML cases were reported. In addition, other issues might theoretically be responsible for the low local prevalence of PML in some areas, such as genomic diversity of JC virus strains, including the possibility of predominance of low virulent strains of JC virus ${ }^{16}$, and host genetic differences.

This study has some limitations, including a relatively low number of patients from a single referral center. A broader source of patients may have improved the generalizability of the findings. In this study only patients with a defined diagnosis of CNS opportunistic diseases were included. Hence, the frequency of PML might have been overestimated. In addition, the retrospective nature of this study imposes several inherent limitations, and an ongoing prospective study might confirm the findings of this report.

In conclusion, PML appears to be a relevant neurological problem in a referral hospital in Brazil and possibly in other centers from developing countries. In this regard, epidemiological prospective studies based on the use of standardized diagnostic protocols are warranted to define the true prevalence of PML in this setting.

\section{RESUMO}

\section{Leucoencefalopatia multifocal progressiva em pacientes com aids: estudo retrospectivo em um centro de referência de São Paulo, Brasil}

Existe informação limitada sobre a presença da leucoencefalopatia multifocal progressiva (LEMP) em pacientes com aids no Brasil. Os objetivos do presente estudo foram descrever as principais características dos pacientes com LEMP e estimar a frequiência desta doença em pacientes com aids e doenças oportunistas do sistema nervoso central (SNC) internados em um centro de referência de São Paulo, Brasil. Neste estudo retrospectivo e descritivo, identificamos $12(6 \%)$ casos de LEMP entre 219 pacientes com doenças neurológicas oportunistas do SNC. A idade média dos pacientes com LEMP foi 36 anos e $9(75 \%)$ eram do sexo masculino. As manifestações clínicas mais freqüentes foram: déficits focais $(75 \%)$, alterações da fala $(58 \%)$, alterações visuais (42\%), alterações cognitivas (42\%), e problemas de coordenação (42\%). A média da contagem de células T-CD4+ foi 45 células/ $\mu \mathrm{L}$. Oito (67\%) dos 12 pacientes com LEMP tiveram diagnóstico confirmado laboratorialmente e em quatro $(33 \%)$ casos o diagnóstico foi possível. Onze (92\%) pacientes apresentaram LEMP clássica e um caso teve LEMP associada à síndrome de reconstituição imune. Em quatro $(33 \%)$ pacientes, a LEMP foi a primeira doença definidora de aids. Durante a internação, três pacientes (25\%) faleceram devido a pneumonia hospitalar e nove $(75 \%)$ tiveram alta. A LEMP foi apenas ultrapassada em freqüência pela toxoplasmose cerebral, a meningoencefalite criptococócica e a neurotuberculose, as três mais freqüientes doenças neurológicas oportunistas no Brasil. Os resultados deste estudo sugerem que a LEMP não é uma complicação neurológica incomum em pacientes com infecção pelo HIV no nosso meio.

\section{ACKNOWLEDGEMENTS}

We thank Paola Cinque, Infectious Disease Unit, S. Raffaele Scientific Institute, Milan, Italy, for helpful advice and discussion.

\section{REFERENCES}

1. BERGER, J.R. - Progressive multifocal leukoencephalopathy in acquired immunodeficiency syndrome: explaining the high incidence and disproportionate frequency of the illness relative to other immunosuppressive conditions. J. Neurovirol., 9( suppl. 1): 38-41, 2003.

2. CHIMELLI, L.; ROSEMBERG, S.; HAHN, M.D.; LOPES, M.B. \& NETTO, M.B. Pathology of the central nervous system in patients infected with the human immunodeficiency virus (HIV): a report of 252 autopsy cases from Brazil. Neuropath. appl. Neurobiol., 18: 478-488, 1992.

3. CINQUE, P.; BOSSOLASCO, S.; BRAMBILLA, A.M. et al. - The effect of highly active antiretroviral therapy-induced immune reconstitution on development and outcome of progressive multifocal leukoencephalopathy: study of 43 cases with review of the literature. J. Neurovirol., 9(suppl. 1): 73-80, 2003.

4. CINQUE, P.; KORALNIK, I.J. \& CLIFFORD, D.B. - The evolving face of human immunodeficiency virus-related progressive multifocal leukoencephalopathy: defining a consensus terminology. J. Neurovirol., 9(suppl. 1): 88-92, 2003.

5. CURY, P.M.; PULIDO, C.F.; FURTADO V.M. \& DA PALMA, F. - Autopsy findings in AIDS patients from a reference hospital in Brazil: analysis of 92 cases. Path. Res. Pract., 199: 811-814, 2003.

6. D'ARMINIO MONFORTE, A.; CINQUE, P.; MOCROFT, A. et al. - Changing incidence of central nervous system diseases in the EuroSIDA cohort. Ann. Neurol., 55: 320$328,2004$.

7. FINK, M.C.; PENALVA DE OLIVEIRA, A.C.; MILAGRES, F.A. et al . - JC virus DNA in cerebrospinal fluid samples from Brazilian AIDS patients with focal brain lesions without mass effect. J. Infect., 52: 30-36, 2006.

8. GÓNGORA-RIVERA, F.; SANTOS-ZAMBRANO, J.; MORENO-ANDRADE, T.; CALZADA-LOPEZ, P. \& SOTO-HERNÁNDEZ, J.L. - The clinical spectrum of neurological manifestations in AIDS patients in Mexico. Arch. med. Res., 31: 393398,2000 .

9. KORALNIK, I.J. - New insights into progressive multifocal leukoencephalopathy. Curr. Opin. Neurol., 17: 365-370, 2004.

10. KORALNIK, I.J. - Progressive multifocal leukoencephalopathy revisited: has the disease outgrown its name? Ann. Neurol., 60: 162-173, 2006.

11. LANJEWAR, D.N.; JAIN, P.P. \& SHETTY, C.R. - Profile of central nervous system pathology in patients with AIDS: an autopsy study from India. AIDS, 12: 309-313, 1998.

12. LUCAS, S.B.; HOUNNOU, A.; PEACOCK, C. et al. - The mortality and pathology of HIV infection in a West African city. AIDS, 7: 1569-1579, 1993.

13. MADAlOSSO, G.; PELlini, A.C.; VASCONCELOS, M.J. et al. - Chagasic meningoencephalitis: case report of a recently included AIDS-defining illness in Brazil. Rev. Inst. Med. trop. S. Paulo, 46: 199-202, 2004.

14. MICHALANY, J.; MATTOS, A.L.; MICHALANY, N.S.; FILIE, A.C. \& MONTEZZO, L.C. - Acquired immune deficiency syndrome (AIDS) in Brazil. Necropsy findings. Ann. Path. (Paris), 7: 15-24, 1987.

15. OLIVEIRA, J.F.; GRECO, D.B.; OLIVEIRA, G.C. et al. - Neurological disease in HIVinfected patients in the era of highly active antiretroviral treatment: a Brazilian experience. Rev. Soc. bras. Med. trop., 39: 146-151, 2006.

16. PAGANI, E.; DELBUE, S.; MANCUSO, R. et al. - Molecular analysis of JC virus genotypes circulating among the Italian healthy population. J. Neurovirol., 9: 559$566,2003$.

17. PORTEGIES, P.; SOLOD, L.; CINQUE, P. et al. - Guidelines for the diagnosis and management of neurological complications of HIV infection. Europ. J. Neurol., 11: 297-304, 2004. 
VIDAL, J.E.; PENALVA DE OLIVEIRA, A.C.; FINK, M.C.D.S.; PANNUTI, C.S. \& TRUJILLO, J.R. - AIDS-related progressive multifocal leukoencephalopathy: a retrospective study in a referral center in São Paulo, Brazil. Rev. Inst. Med. trop. S. Paulo, 50(4): 209-212, 2008.

18. PUCCIONI-SOHLER, M.; CORREA, R.B.; PEREZ, M.A. et al. - Neurological complications in acquired immunodeficiency syndrome: experience at the Hospital Universitário Clementino Fraga Filho-Universidade Federal do Rio de Janeiro. Arq. Neuro-psiquiat. (S. Paulo), 49: 159-163, 1991.

19. ROBERTS, M.T. - AIDS-associated progressive multifocal leukoencephalopathy: current management strategies. CNS Drugs, 19: 671-682, 2005.

20. ROSEMBERG, S.; LOPES, M.B. \& TSANACLIS, A.M. - Neuropathology of acquired immunodeficiency syndrome (AIDS). Analysis of 22 Brazilian cases. J. neurol. Sci., 76: 187-198, 1986.

21. SACKTOR, N. - The epidemiology of human immunodeficiency virus-associated neurological disease in the era of highly active antiretroviral therapy. J. Neurovirol., 8(suppl. 2): 115-121, 2002.

22. SHANKAR, S.K.; SATISHCHANDRA, P.; MAHADEVAN, A. et al. - Low prevalence of progressive multifocal leukoencephalopathy in India and Africa: is there a biological explanation? J. Neurovirol., 9(suppl. 1): 59-67, 2003.
23. VIDAL, J.E.; FINK, M.C.; CEDENO-LAURENT, F. et al. - BK virus associated meningoencephalitis in an AIDS patient treated with HAART. AIDS Res. Ther., 4: $13,2007$.

24. VIDAL J.E.; HERNANDEZ, A.V.; PENALVA DE OLIVEIRA, A.C. et al. - Cerebral toxoplasmosis in HIV-positive patients in Brazil: clinical features and predictors of treatment responser in the HAART era. AIDS Patient Care and STDS, 19: 626634, 2005.

25. WAINSTEIN, M.; FERREIRA, L.; WOLFENBUTTEL, L. et al. - The neuropathologica findings in the acquired immunodeficiency syndrome (AIDS): a review of 138 cases. Rev. Soc. bras. Med. trop., 25: 95-99, 1992

Received: 11 October 2007

Accepted: 12 May 2008 